\title{
Horse Gram Seed Germination Inhibition Profiles in Response to Antimitotic Compounds
}

\author{
Akshatha G. Athreya ${ }^{1}$, Mrinalini Menon² \\ ${ }^{1}$ Senior Research Fellow, School of Ecology and Environment, \\ University of Agricultural Sciences, GKVK, Bangalore-560065, India \\ ${ }^{2}$ Associate Professor, Department of Biotechnology, Sir M Visvesvaraya Institute of Technology, \\ International Airport Road, Hunasamaranahalli Bangalore-562157, India
}

\begin{abstract}
Seed germination inhibition in green gram (Phaseolus radiatus) by compounds inhibitory to cell division has previously formed the basis of an in vitro assay system for the identification of these potential drugs. Presently, we are extending the scope of these studies, using the germinating seeds of another legume, namely horse gram (Macrotyloma uniflorum) as a model system. We report that the horse gram seed germination was maximally inhibited by vinblastine and the cancer palliative herbal drug HST-K drug, derived from Asteracantha longifolia (Patent No.GB2454875 A) as evident from profiles of seed weight and selected hydrolytic enzymes, measured over 24-120h. We propose that the seed germination inhibition assay deserves to be evaluated with different species of seeds for the identification of antimitotic compounds that could serve as potentially efficacious remedies with fewer side effects posed during the treatment of malignant disorders.
\end{abstract}

Keywords: Enzyme inhibition, herbal, horsegram, malignancies, germination

\section{Introduction}

Inhibition of germination in green gram, following incubation with antimitotic drugs was previously elucidated in terms of reduced imbibition, altered morphology [1,2] and enzyme profiles [3]. Drugs used in these studies included vincristine and vinblastine, besides extracts of Calotropis procera [1] and the HST-K drug (Kokilaksha) derived from Asteracantha longifolia [2, 3]. The efficacy of herbal drugs has been estimated in terms of their ability to inhibit enzymes whose activity is enhanced during disease progression [4]. Amylolytic and alkaline phosphatase activity were thus chosen for our studies against green gram since the elevation of these enzymes has been reported both during seed germination [3] as well as during the progression of various benign and malignant disorders [5-6]. Since seed germination inhibition has been described as a cost-effective method for preliminary identification of potential antimitotic compounds $[1,2]$, we sought to extend our observations to different seed species, besides green gram with a view to evaluating the scope of the seed germination inhibition method.

In this connection, our preliminary observations revealed that horse gram seed germination was influenced to a greater extent by antimitotic drugs such as HST-K, vinblastine and vincristine. Therefore, we considered it worthwhile to explore the response of growth parameters previously studied by us, in green gram with reference to horse gram. These parameters consisted of alterations in:-

- Seed weight and onset of morphogenesis.

- Specific activity profiles of amylase and alkaline phosphatase.

\section{Materials and Methods}

All reagents were procured from standard manufacturers, namely Sigma, Hi-Media and Merck or were of analytical/reagent grade. Vinblastine and vincristine were obtained from the Kidwai Institute of Oncology Bangalore. The HST-K or Kokilaksha formulation (Patent No.GB2454875 dated $20^{\text {th }}$ Nov, 2007), was provided by the Herbal Science Trust Bangalore. Horse gram (Macrotyloma uniflorum ) seeds were obtained from the local markets.

\section{Seed Treatment and Crude Enzyme Extract Preparation}

Horse gram seeds $(0.5 \mathrm{gm})$ were soaked in distilled water (control) or the test drugs at different concentrations. The test and control plates were incubated for 24, 48, 72, 96 and 120 $\mathrm{h}$ respectively at room temperature. Following incubation, excess moisture was removed from the seedlings by blotdrying them on paper towels, after which the fresh weight of the seedlings was recorded as cited in ref [3]. The seedlings were homogenized at $4^{\circ} \mathrm{C}$ and clarified by centrifugation at $10,000 \mathrm{Xg}$ at $4^{0} \mathrm{C}$ for $10 \mathrm{~min}$, to obtain the supernatant which constituted the source of the enzyme as had been previously performed [3].

Drugs Used: The K-drug was diluted 1:5 v/v and 1:20 v/v with distilled water as previously described $[2,3]$. Vincristine was chosen for comparison, having been previously used by us in our studies involving green gram $[2,3]$. Additionally, we also chose vinblastine for our study since studies indicated that this drug had shown inhibitory activity against green gram as measured at the end of $24 \mathrm{~h}$ by the imbibition method [2]. The commercially available stock solutions of both the drugs $(1.0 \mathrm{mg} / \mathrm{mL})$ were diluted to final concentrations of $0.05 \mathrm{mg} / \mathrm{mL}$ and $0.2 \mathrm{mg} / \mathrm{mL}$ with distilled water respectively. The $\mathrm{pH}$ of all the solutions was found to be 6.5-7.0 as cited previously [3], thus ruling out the likelihood of $\mathrm{pH}$-induced variations [7]

Amylase Assay: Amylase activity was measured by estimating the residual starch using the starch-iodine method [8]. Suitable blanks, devoid of substrate and containing aciddenatured enzyme served for comparison. One unit of 


\section{International Journal of Science and Research (IJSR) \\ ISSN (Online): 2319-7064 \\ Index Copernicus Value (2013): 6.14 | Impact Factor (2015): 6.391}

amylase activity was equal to the decrease in absorbance of the starch-iodine complex by $0.01 \mathrm{~A}$ at $580 \mathrm{~nm}$ measured at $37^{\circ} \mathrm{C}$ under the assay conditions.

Alkaline Phosphatase Assay: Alkaline phosphatase activity was measured by the method of Nigam and Aiyyagari, 2008 [9]. One unit of activity was equal to the amount of enzyme required to release $10 \mu \mathrm{M}$ of $\mathrm{p}$-nitrophenol by the hydrolysis of p-nitrophenyl phosphate under the conditions of the assay.

Protein Estimation: Protein was routinely estimated by the Coomassie G-250 dye -binding method of Bradford, 1976 [10], using bovine serum albumin as standard.

Units Of Comparison: Specific enzyme activity (Units/mg) was estimated by dividing the total units of enzyme activity by the total protein content.

Specific enzyme activity $=$ Total enzyme activity (units) Total protein content ( $\mathrm{mg}$ )

Statistical Tools: Results were expressed as an average of 4 trials \pm standard error in all cases except for weight profiles, where an average of 5 trials \pm standard error was used in calculations. Statistical differences between the specific enzyme activities of the control and the test categories were determined by ANOVA followed by two-sided Dunnett analysis. $\mathrm{P}$ values $\leq 0.05$ were considered significant.

\section{Results}

\subsection{Alterations in seed weight}

The initial weight of seeds taken ( 5 trials) was equal to $0.51 \pm 0.01 \mathrm{gm}$. Following imbibition for $24 \mathrm{~h}$ with distilled water/ drug solutions, all the seeds exhibited a similar increase in weight. However, the weight of seeds in the control group exhibited a fold increase of $3.1 \pm 0.04$ over 24 120h. During this period, the weight of HST-K drug (1:5 v/v) and vinblastine $(0.2 \mathrm{mg} / \mathrm{ml})$ treated seeds exhibited no further increase in weight. Therefore we considered it worthwhile to dilute the K-drug 20-fold with distilled water. Seeds incubated with the 1:20 v/v diluted K-drug exhibited a $1.6 \pm 0.1$-fold increase in seed weight over 24-120h (Fig 1).

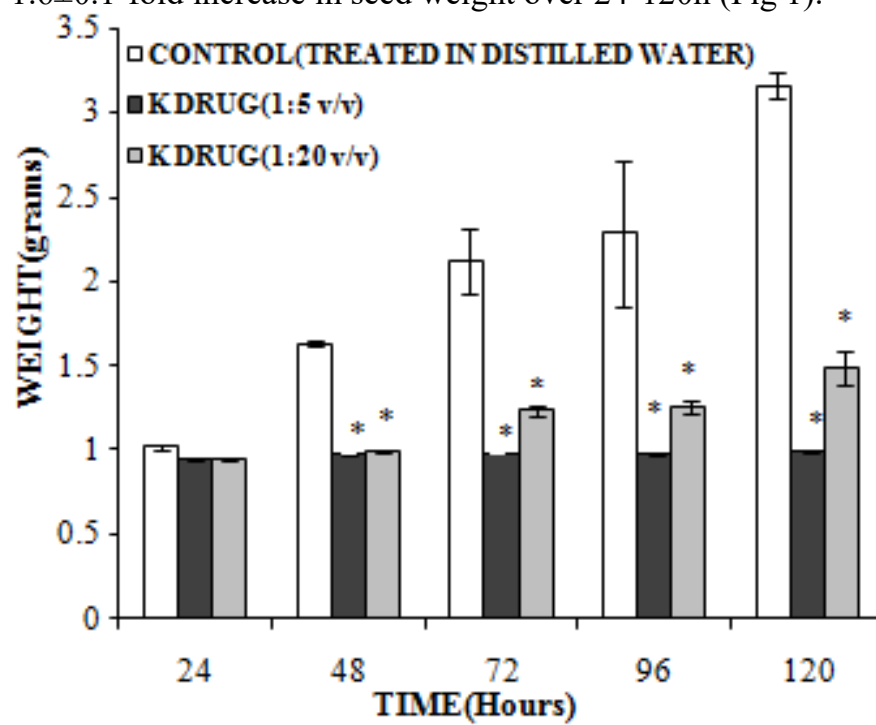

Figure 1: Weight profiles of horsegram seeds germinated in the presence of the HST-K drug vis-à-vis control : Readings represent the average of 5 trials \pm S.E. Significant statistical differences indicated by an asterisk $(*)$.

Correspondingly, stock solutions of vinblastine and vincristine $(1.0 \mathrm{mg} / \mathrm{ml})$ were also diluted 20 -fold to final concentrations of $0.05 \mathrm{mg} / \mathrm{ml}$ for seed treatment. Weight of the K-drug treated seeds was significantly less than the control between $48-120 \mathrm{~h}$, at both the concentrations of the drug $(\mathrm{p}<0.05)$. However weights of seeds treated with vinblastine at $0.05 \mathrm{mg} / \mathrm{ml}$ were significantly inhibited only at the end of $48 \mathrm{~h}$ and $72 \mathrm{~h}$ period $(\mathrm{p}<0.05)$ beyond which there was no significant difference vis-a-vis control (Fig 2).

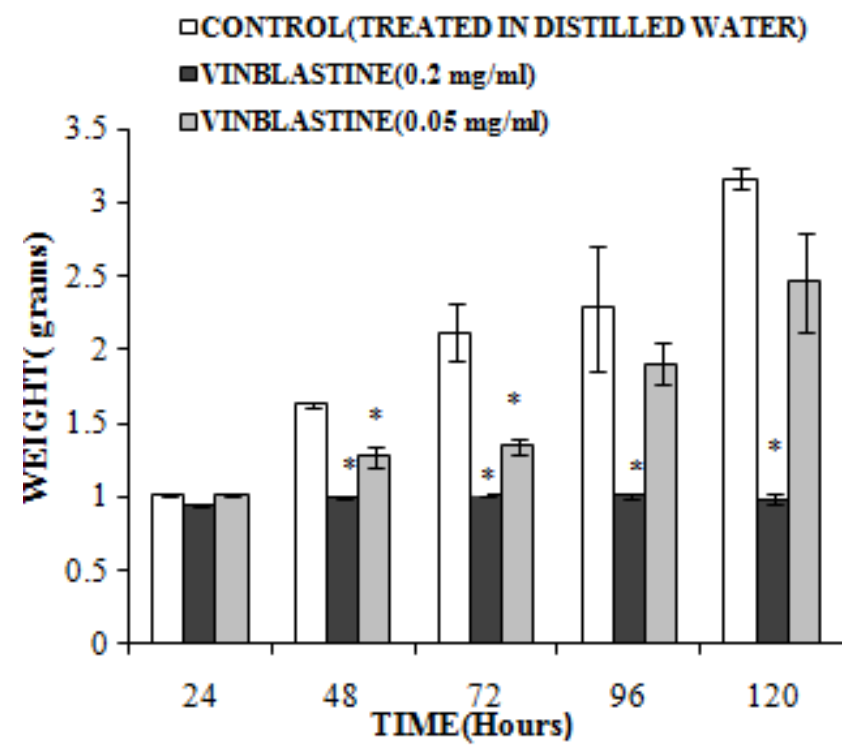

Figure 2: Weight profiles of horsegram seeds germinated in the presence of vinblastine vis-à-vis control :Readings represent the average of 5 trials \pm S.E. Significant statistical differences indicated by an asterisk $\left(^{*}\right)$.

Vincristine-treated seed weights were significantly lower than the control at $0.2 \mathrm{mg} / \mathrm{ml}(\mathrm{p}<0.05)$ but not at $0.05 \mathrm{mg} / \mathrm{ml}$ $(\mathrm{p}>0.05)$ concentration of the drug tested over the $48-120 \mathrm{~h}$ incubation (Fig 3).

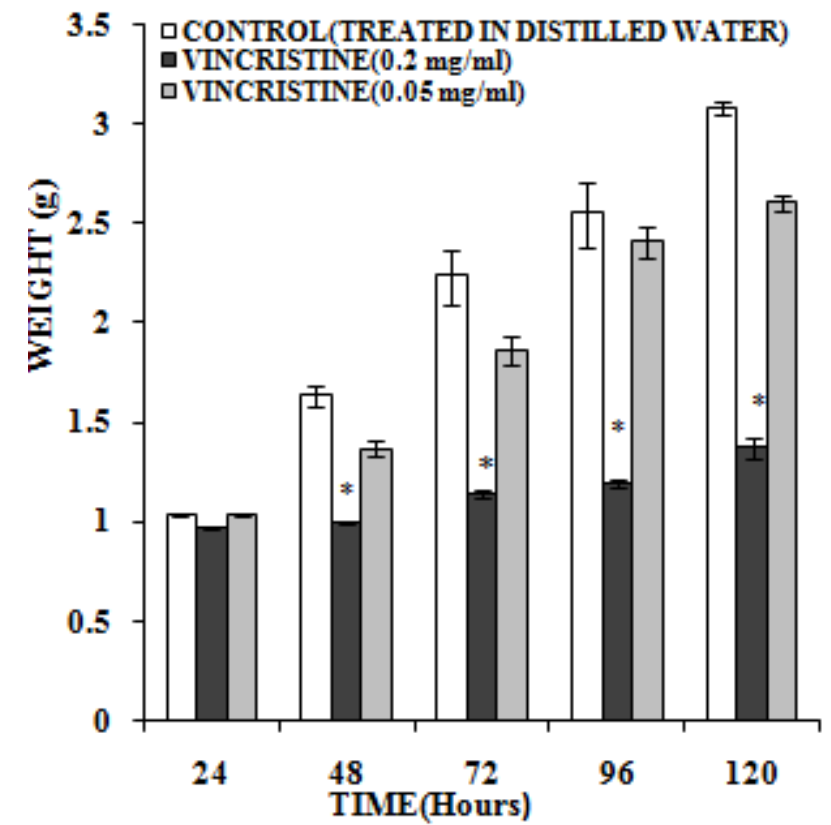

Figure 3: Weight profiles of horsegram seeds germinated in the presence of vincristine vis-à-vis control :Readings 


\section{International Journal of Science and Research (IJSR) \\ ISSN (Online): 2319-7064}

Index Copernicus Value (2013): 6.14 | Impact Factor (2015): 6.391

represent the average of 5 trials \pm S.E. Significant statistical differences indicated by an asterisk $(*)$.

\subsection{Alterations in amylolytic activity}

Specific amylolytic activity in the control group exhibited a $9.5 \pm 1.6$ fold increase between $24-120 \mathrm{~h}$ of incubation. (Fig $4)$.

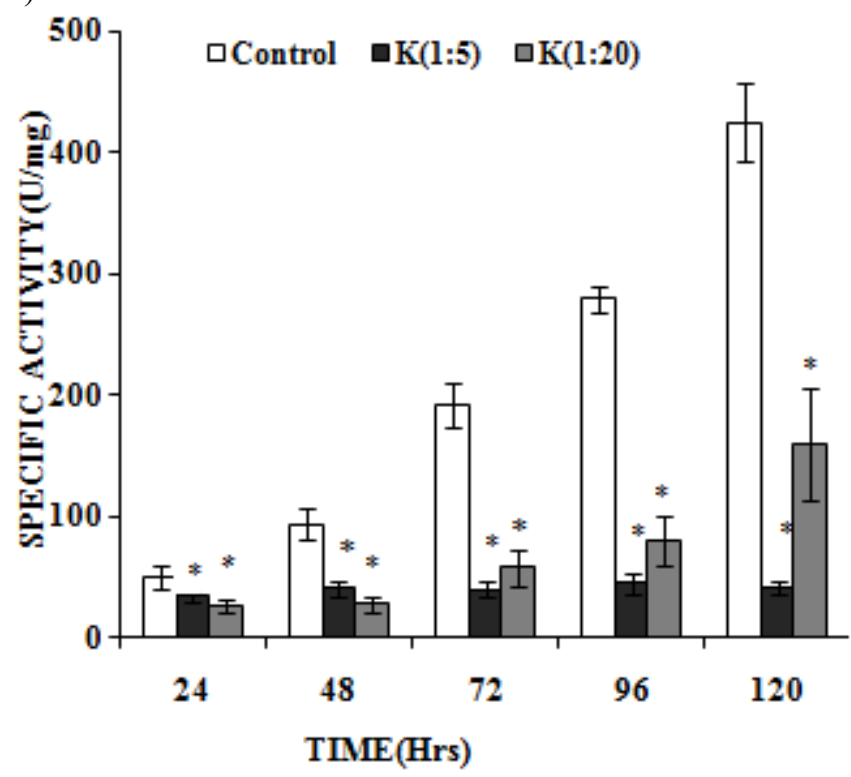

Figure 4: Amylolytic activity profiles of horsegram seeds germinated in the presence of $\mathbf{K}$-drug vis-à-vis control : Readings represent the average of 4 trials \pm S.E. Significant statistical differences indicated by an asterisk $(*)$.

At the end of $120 \mathrm{~h}$ the specific amylolytic activity was calculated as $425.5 \pm 31.6$ units $/ \mathrm{mg}$ protein in the control. Specific amylolytic activities of the $1: 5 \mathrm{v} / \mathrm{v}$ and 1:20 v/v diluted HST-K drug-treated seeds at the end of $120 \mathrm{~h}$ were equal to $41.7 \pm 5.1$ and $159.3 \pm 45.8$ units $/ \mathrm{mg}$ protein, thus registering a 1.25 -fold and 6.15-fold increase over the 24$120 \mathrm{~h}$ period, respectively. At all the time points tested, the specific amylolytic activity at both concentrations of the $\mathrm{K}$ drug were found to be significantly less than the control $(\mathrm{n}=4, \mathrm{p}<0.05) \quad$ Vinblastine treated seeds also displayed specific amylolytic activity of $32.1 \pm 2.0$ and $200.4 \pm 21.4$ units/mg protein at both concentrations of the drug following $120 \mathrm{~h}$ incubation (Fig 5).

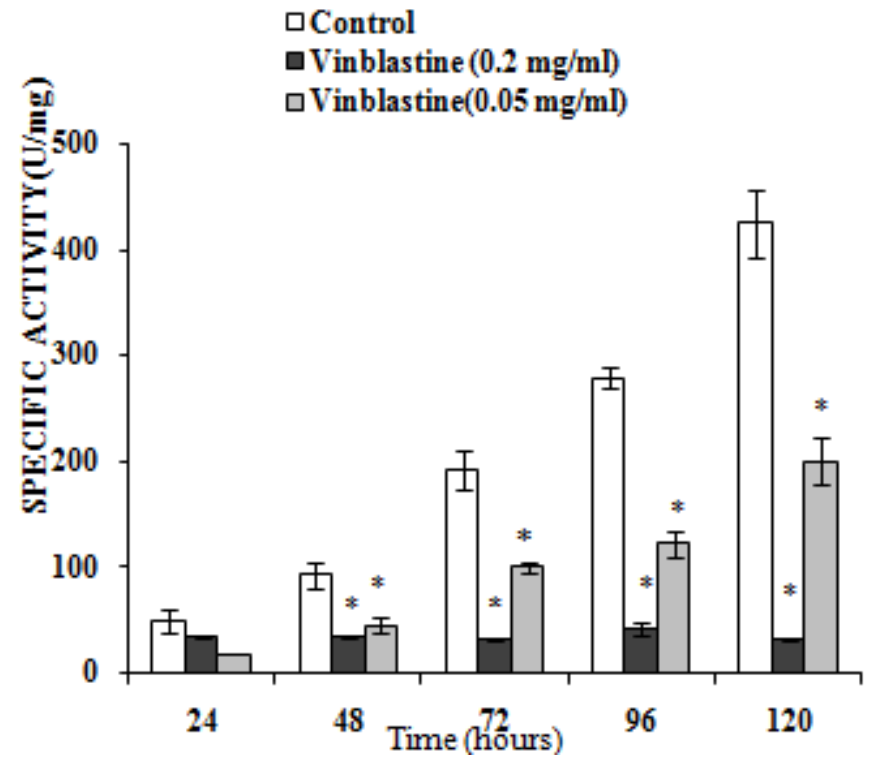

Figure 5: Amylolytic activity profiles of horsegram seeds germinated in the presence of vinblastine vis-à-vis control : Readings represent the average of 4 trials \pm S.E. Significant statistical differences indicated by an asterisk (*).

Thus the residual specific activity at the end of $120 \mathrm{~h}$ following exposure to the lower concentration of vinblastine was only $47 \%$ of the activity observed in the control. At both concentrations of the drug, two-sided Dunett analysis revealed significant inhibition of specific amylolytic activity vis-a-vis control $(n=4, p<0.05)$ at all the time points except the initial $24 \mathrm{~h}(\mathrm{n}=4, \mathrm{p}>0.05)$.

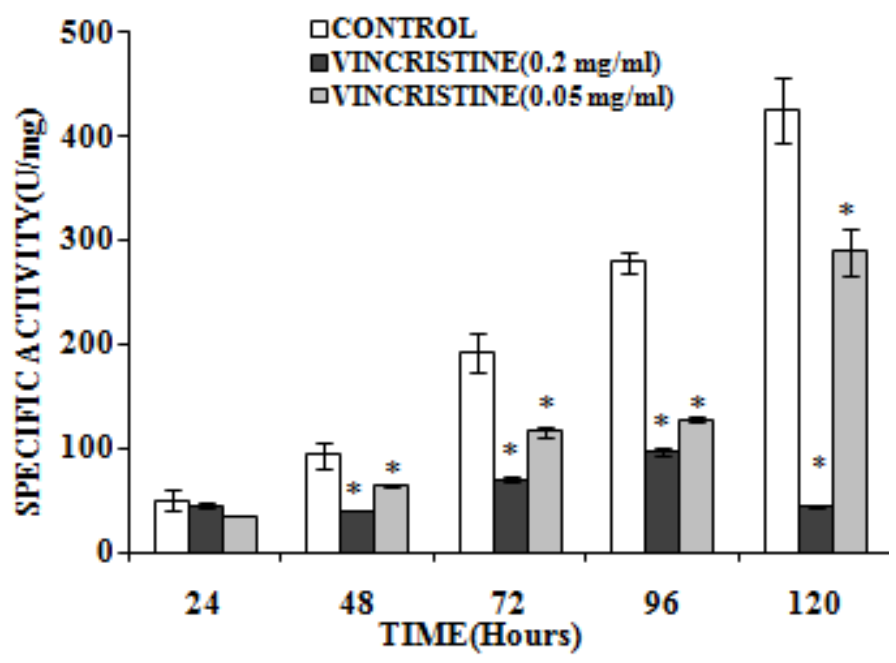

Figure 6: Amylolytic activity profiles of horsegram seeds germinated in the presence of vincristine vis-à-vis control :Readings represent the average of 4 trials \pm S.E. Significant statistical differences are indicated by an asterisk $\left(^{*}\right)$.

As evident from Fig 6, a similar inhibition profile was observed following vincristine treatment, wherein significant inhibition of specific amylolytic activity was achieved upon incubation between $48-120 \mathrm{~h}$.

\subsection{Alterations in alkaline phosphatase activity}

The specific activity of alkaline phosphatase showed a $6.2 \pm$ 0.5 fold increase in the control group between 24-120h of incubation. In contrast however, the specific alkaline 


\section{International Journal of Science and Research (IJSR) \\ ISSN (Online): 2319-7064}

Index Copernicus Value (2013): 6.14 | Impact Factor (2015): 6.391

phosphatase activity registered only a $1.45 \pm 0.01$ fold increase over the same period in response to the $1: 20 \mathrm{v} / \mathrm{v}$ diluted HST-K drug.

Upon treatment with the $1: 5 \mathrm{v} / \mathrm{v}$ diluted HST-K drug, a feeble fold-difference of $0.76 \pm 0.04$ was observed over the same period (Fig 7). The specific alkaline phosphatase activity was significantly inhibited by both concentrations of the HST-K drug $(n=4, p<0.05)$ at the end of all the incubation time points except the initial $24 \mathrm{~h}$ period.

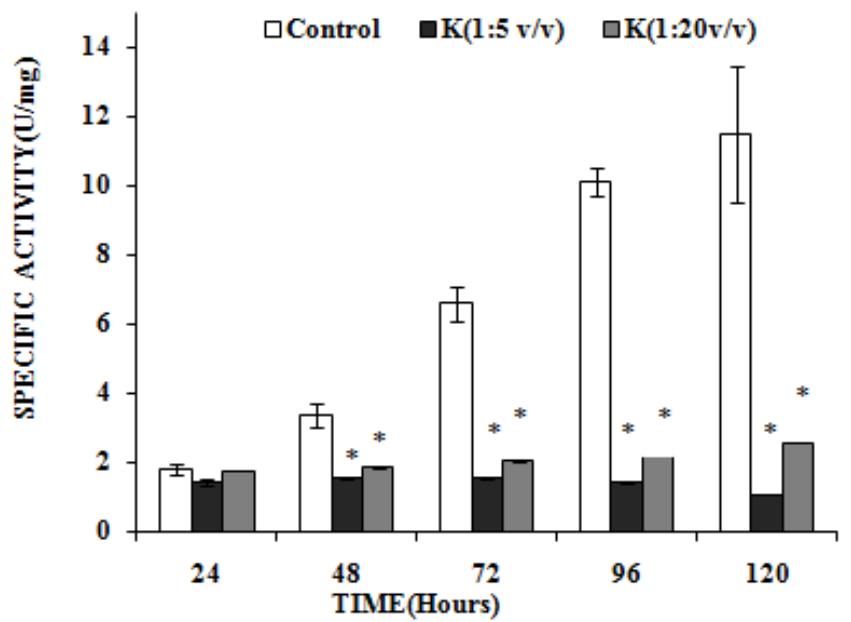

Figure 7: Alkaline phosphatase activity profiles of horsegram seeds germinated in the presence of $\mathrm{K}$ drugvis-à-vis control: Readings represent the average of 4 trials \pm S.E. Significant statistical differences indicated by an asterisk (*).

Following observations on dose-dependent inhibition of alkaline phosphatase, following treatment with the HST-K drug, the effects of vinblastine and vincristine were also determined in this regard.

Seeds treated with $0.05 \mathrm{mg} / \mathrm{ml}$ vinblastine exhibited a foldincrease of $2.75 \pm 0.03$ with respect to specific alkaline phosphatase activity between 24-120h, while treatment with $0.2 \mathrm{mg} / \mathrm{ml}$ vinblastine, activity was arrested over the same period.

Significant inhibition of specific alkaline phosphatase activity was observed at both concentrations of vinblastine $(\mathrm{n}=4, \mathrm{p}<0.05)$ at the end of all the incubation time points except the initial $24 \mathrm{~h}$ period as shown in Fig 8.

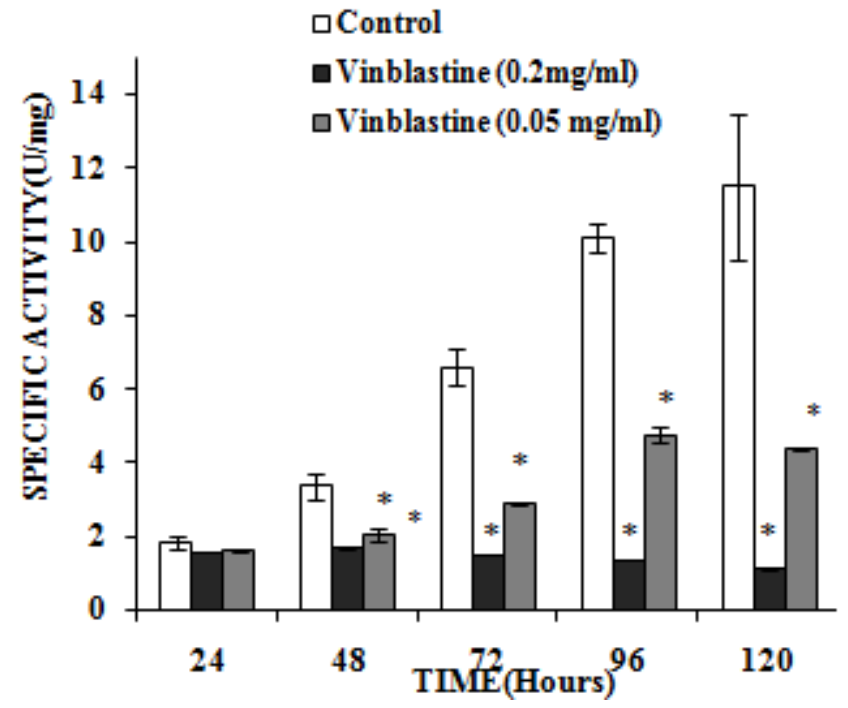

Figure 8: Alkaline phosphatase activity profiles of horsegram seeds germinated in the presence of vinblastine vis-à-vis control: Readings represent the average of 4 trials \pm S.E. Significant statistical differences indicated by an asterisk $(*)$.

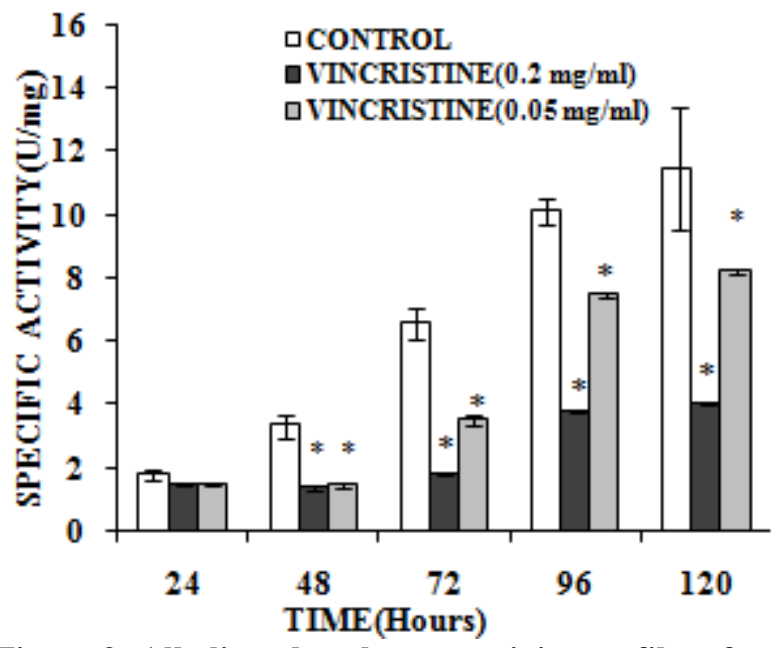

Figure 9: Alkaline phosphatase activity profiles of horsegram seeds germinated in the presence of vincristine vis-à-vis control: Readings represent the average of 4 trials \pm S.E. Significant statistical differences indicated by an asterisk $(*)$.

As indicated in Fig 9, despite a 4.1-fold increase in specific alkaline phosphatase activity between 24-120h upon treatment with $0.05 \mathrm{mg} / \mathrm{ml}$ vincristine, such activity was significantly less than the control $(n=4, p<0.05)$ at all the time points tested. However there was a 2.1 -fold increase in specific alkaline phosphatase activity between $24-120 \mathrm{~h}$ upon treatment with $0.2 \mathrm{mg} / \mathrm{ml}$ vincristine.

\subsection{Alterations in the onset of morphogenesis}

Seeds germinated in the presence of the lower concentrations of HST-K and vinblastine exhibited a 24h-long delay vis-àvis control for the onset of morphogenesis with respect to seed coat rupture, hypocotyl emergence, radicle and leaf development. At the higher concentration of both these drugs, morphogenesis was completely inhibited. However morphogenesis, culminating in hypocotyl development occurred in the case of the seeds germinated in the presence of $0.2 \mathrm{mg} / \mathrm{ml}$ vincristine, while at lower concentrations, the time of onset of morphogenesis was similar to the control. 


\section{International Journal of Science and Research (IJSR) \\ ISSN (Online): 2319-7064 \\ Index Copernicus Value (2013): 6.14 | Impact Factor (2015): 6.391}

Table1: Onset of Morphogenesis in horsegram seeds germinated in the presence of different drugs vis-à-vis control

\begin{tabular}{|c|c|c|c|c|c|}
\hline & Drug concentration & Rupture of seed coat & Hypocotyl emergence & Radicle development & Leaf formation \\
\hline Control & 0 & $24 \mathrm{~h}$ & $48 \mathrm{~h}$ & $72 \mathrm{~h}$ & $96 \mathrm{~h}$ \\
\hline \multirow[t]{2}{*}{ K-drug } & 1:5(v/v) water-diluted & Absent & Absent & Absent & Absent \\
\hline & $1: 20(\mathrm{v} / \mathrm{v})$ water-diluted & $48 \mathrm{~h}$ & $72 \mathrm{~h}$ & $96 \mathrm{~h}$ & $120 \mathrm{~h}$ \\
\hline \multirow[t]{2}{*}{ Vinblastine } & $0.2 \mathrm{mg} / \mathrm{mL}$ & Absent & Absent & Absent & Absent \\
\hline & $0.05 \mathrm{mg} / \mathrm{mL}$ & $48 \mathrm{~h}$ & $72 \mathrm{~h}$ & $96 \mathrm{~h}$ & $120 \mathrm{~h}$ \\
\hline \multirow[t]{2}{*}{ Vincristine } & $0.2 \mathrm{mg} / \mathrm{mL}$ & $48 \mathrm{~h}$ & $72 \mathrm{~h}$ & Absent & Absent \\
\hline & $0.05 \mathrm{mg} / \mathrm{mL}$ & $24 \mathrm{~h}$ & $48 \mathrm{~h}$ & $72 \mathrm{~h}$ & $96 \mathrm{~h}$ \\
\hline
\end{tabular}

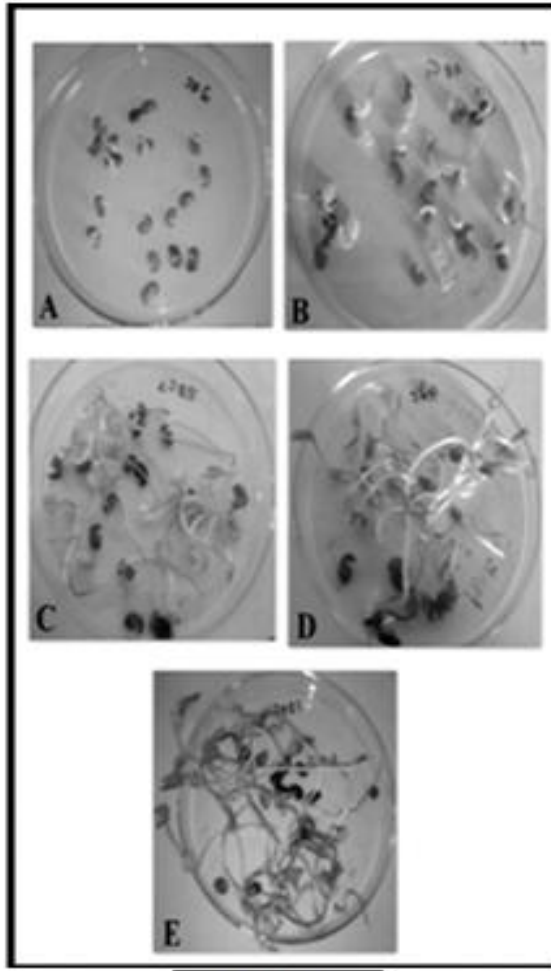

Control

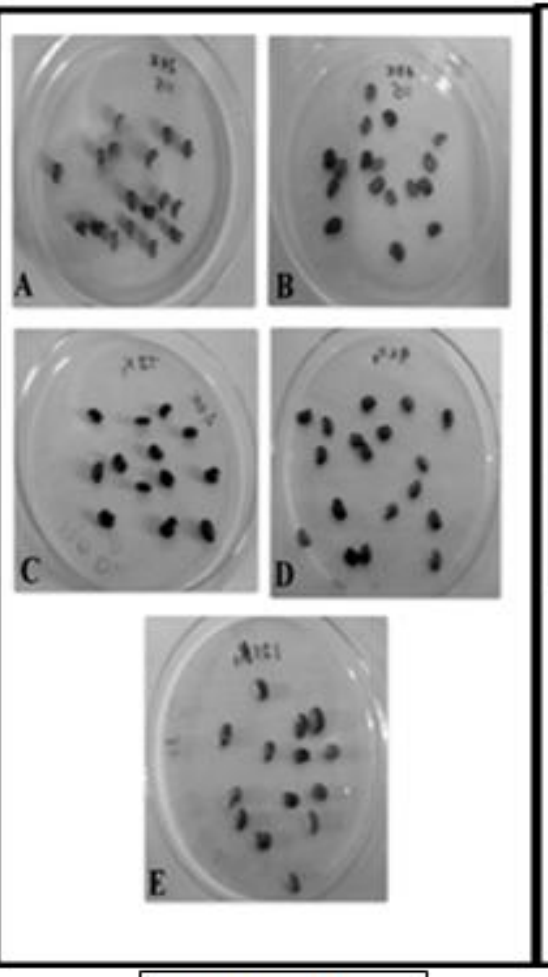

$\operatorname{HST}-\mathrm{K}(1: 5 \mathrm{v} / \mathrm{v})$
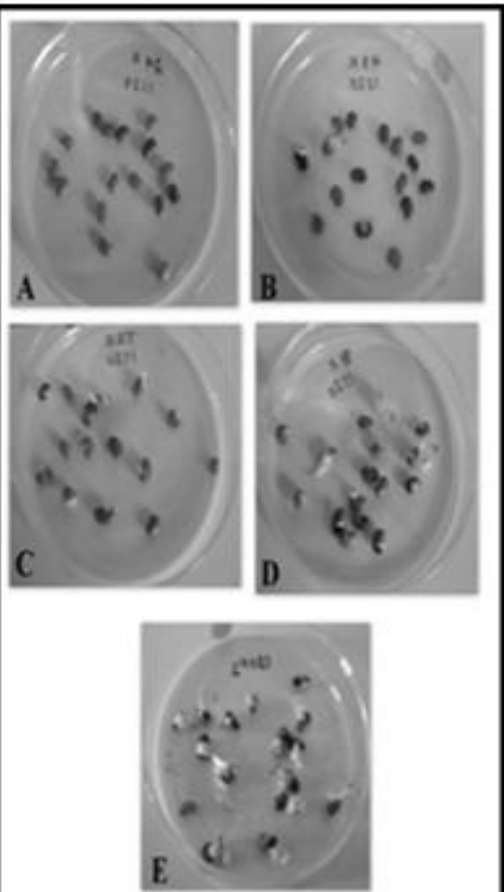

HST-K $(1: 20 \mathrm{v} / \mathrm{v})$

Figure 10: a) Morphological changes in green gram seeds treated with: I: Control (distilled water); II: 1/5 v/v diluted K-drug; III: 1/20 v/v diluted K-drug. A:24h B:48h C:72h D:96h E:120h

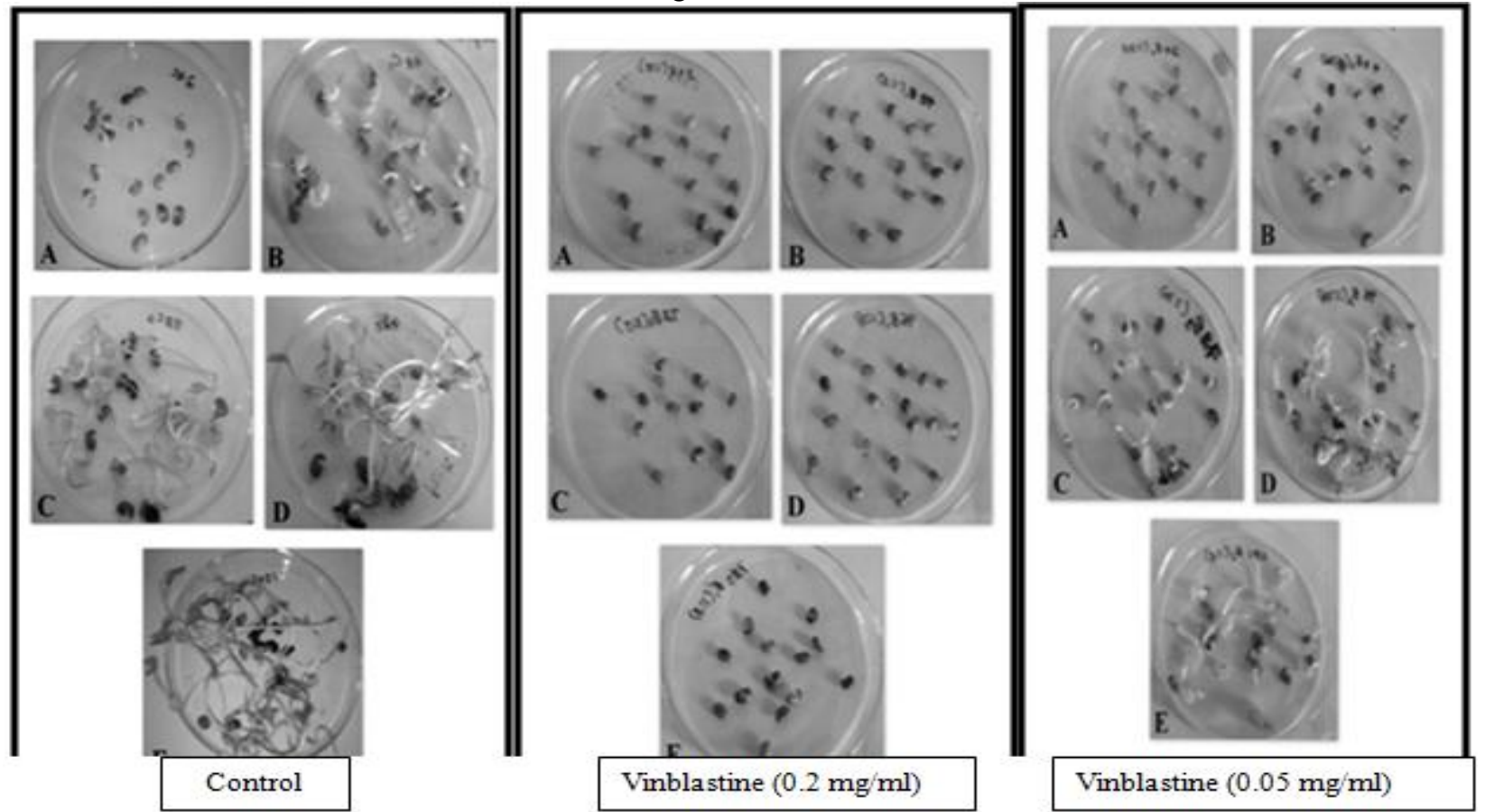

Figure 10 b) Morphological changes in green gram seeds treated with: I: Control (distilled water); II: Vinblastine $=0.2$ $\mathrm{mg} / \mathrm{ml}$; III: Vinblastine $=0.05 \mathrm{mg} / \mathrm{ml}$ diluted K-drug. A:24h B:48h C:72h D:96h E:120h

\section{Volume 5 Issue 4, April 2016}




\section{International Journal of Science and Research (IJSR) \\ ISSN (Online): 2319-7064}

Index Copernicus Value (2013): 6.14 | Impact Factor (2015): 6.391

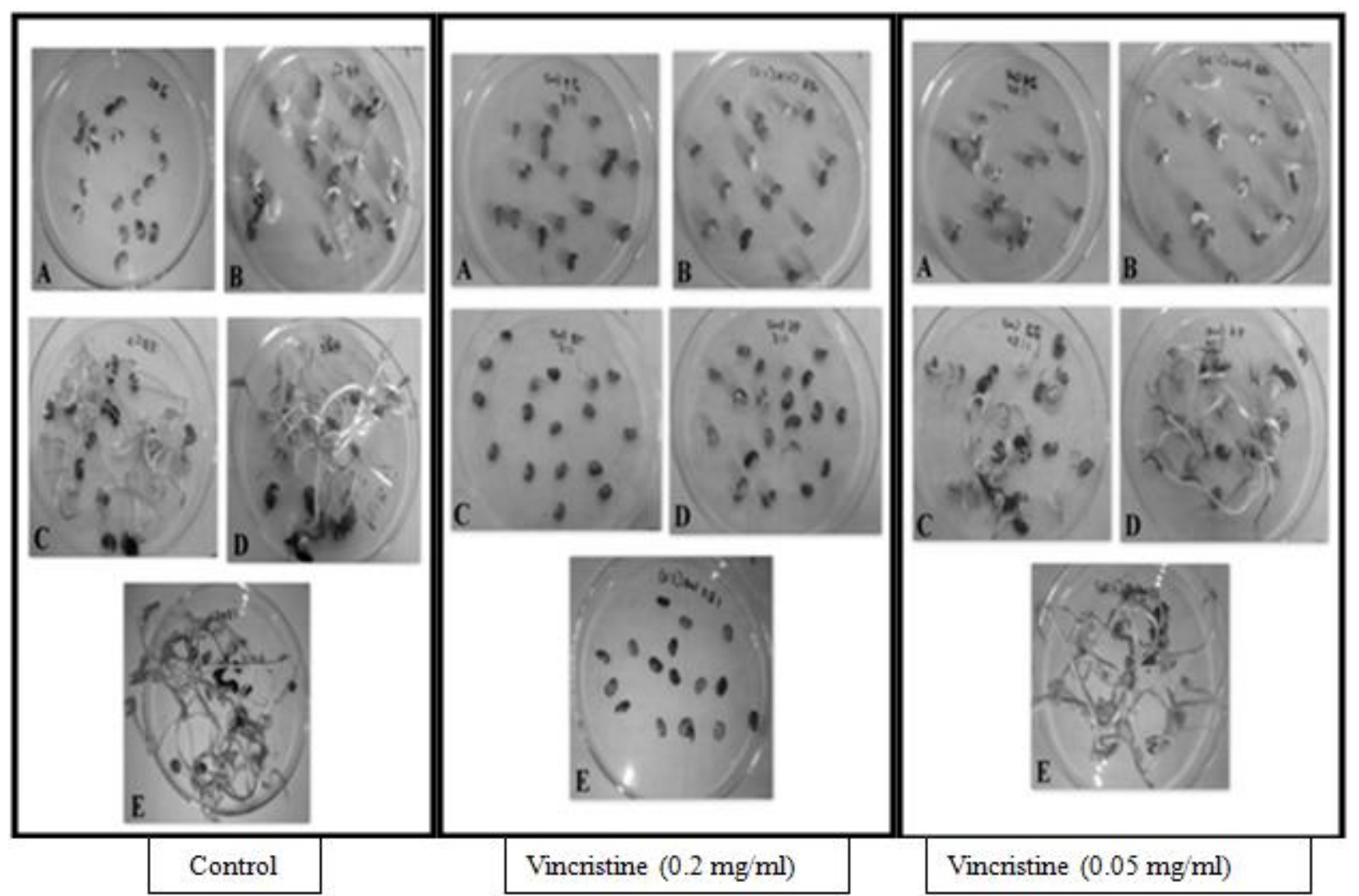

Figure 10: c) Morphological changes in green gram seeds treated with: I: Control (distilled water); II: Vincristine $=0.2$ $\mathrm{mg} / \mathrm{ml}$; III: Vincristine $=0.05 \mathrm{mg} / \mathrm{ml}$ diluted K-drug. A:24h B:48h C:72h D:96h E:120h

\section{Discussion}

Our studies indicate that horse gram seed germination was significantly inhibited by the HST K-drug, as reflected by reduced seed weight by water imbibition, delayed morphogenesis and reduced amylolytic and alkaline phosphatase activities. Significant inhibition of these parameters was also observed in response to vinblastine treatment. Moreover, horse gram was also observed to be inhibited by vincristine to a greater extent than green gram. It may be noted that our previous investigations revealed the absence of significant inhibition of green gram by vincristine beyond $72 \mathrm{~h}$ even at $0.2 \mathrm{mg} / \mathrm{ml}$ concentration [3].

Aqueous extracts of Asteracantha longifolia (from which the HST-K drug was derived) displayed hepatoprotective properties in liver-damaged rats, while a three-week treatment with the petroleum-soluble fraction of the roots yielded significant reduction in tumor fluid in tumor-bearing mice [11]. Similarly, antitumor properties of the methanolic whole plant extract against DMBA-induced mammary tumors, were reported in Sprague Dawley rats. In this particular study, significant increase in activities of antioxidant enzymes such as SOD and catalase were reported following the administration of Asteracantha longifolia extracts [12]. We suggest that serum amylolytic and alkaline phosphatase activities deserve to be monitored in similar tumor-bearing animal models treated with the extracts of the plant. On similar lines, the efficacy of the K-drug derived from the same source, may also be assessed for its efficacy in tumor regression.
Hyperamylasemia has been reported in various malignant conditions $[6,13]$. Interestingly, in vitro cancer cytotoxicity accompanied by inhibition of amylolytic activity has also been reported in the case of fruit residues [14], though this study did not correlate amylolytic activity specifically to cancer. Studies indicate that vinblastine, which has been used as a reference for comparison in our present study, inhibited cholinergic stimulation of pancreatic hyperamylasemia in rats, while not significantly affecting basal levels of the enzyme in normal tissues [15].

Similarly, elevated alkaline phosphatase has been reported in various malignancies $[5,16,17]$. When used in combination therapy, vinblastine restored elevated serum alkaline phosphatase levels to normal, thus improving the longevity of patients with advanced urothelial tract tumors. [17]

While vinblastine has been indicated for the treatment of various cancers, adverse hematological events such as damage to RBC membranes have been observed following treatment with this drug [18], whereas the Asteracantha longifolia extract (source of the K-drug) enhanced hematopoietic activity in anemic albino rats [19]. Grade 1 or 2 anemia was also reported in a significant number of nonsmall cell lung cancer (NSCLC) patients receiving vinblastine in combination therapy [20]. Our present studies indicate that the HST-K-drug and vinblastine exhibited similarity with respect to inhibition profiles. It would therefore be worthwhile to clinically investigate the likelihood of HST-K drug as a possible cost-effective and safer alternative to vinblastine. 


\section{International Journal of Science and Research (IJSR) \\ ISSN (Online): 2319-7064}

Index Copernicus Value (2013): 6.14 | Impact Factor (2015): 6.391

Likewise, adverse effects have also been reported for vincristine therapy [21]-[23], which should be considered despite the fact that vincristine inhibited horse gram significantly as compared to its inhibition of green gram [3]. The efficacy of the K-drug therefore deserves to be compared vis-à-vis both vinblastine as well as vincristine in clinical trials. Presently the IC-50 of the K-drug against these horse gram enzymes is also being calculated.

To summarize, we wish to emphasize the following:-

i) Both the HST-K drug and vinblastine were observed to bring about significant inhibition of horse gram.

ii) Clinical investigations deserve to be conducted on the HST-K drug since it could possibly offer safer alternatives to existing remedies.

iii) While green gram has served till date, as the model system for studies of this nature $[1,2,3]$, our present results indicate that the response of other seed systems such as horse gram also deserves to be explored and validated with respect to cell line and animal studies at the pre-clinical stage. This would, in our opinion, enable the exploration of safer remedies for cancer, the dreaded disease. Besides, if validated against animal models, the horse gram seed assay could even provide a cost-effective alternative to cell lines or animal testing, in the future.

\section{Acknowledgement}

We owe our grateful thanks to the Visvesvaraya Technological University (VTU), Belgaum for the award of the VTU Research Grant that enabled part of these studies. We also thank Prof.H.G Nagendra (Prof and Head, Dept.of Biotechnology, Sir MVIT) and Dr.M.S Indira (Principal, Sir MVIT) for their kind support and encouragement. Grateful thanks is also accorded to the Herbal Science trust (HST) for all the help rendered.

\section{Conflict of Interest}

None

\section{References}

[1] Kumar, V.L, Singhal, A (2009)- Germinating seeds of the mung bean, Vigna radiata (Fabaceae), as a model for the preliminary evaluation of cytotoxic effects of drugs- BIOCELL, 33: 19-24.

[2] Murthy, G.S., Francis, T. P., Singh, C. R., Nagendra, H. G. and Naik ,C (2011) - An assay for screening antimitotic activity of herbal extracts- Curr.Sci 100 : 14011404.

[3] Deepthi, K. and Menon, M. (2015)-Altered enzyme activity in green gram seeds treated with antimitotic herbal drugs- International Journal of Current Research $7: 17217-17223$.

[4] Sumantran, V.N (2010)- Novel approaches for activitybased standardization of herbal drugs- Curr.Sci. 98: 610-611.

[5] Wiwanitki, V. (2001)- High serum alkaline phosphatase levels, a study in 181 Thai adult hospitalized patients - BMC Family Practice 2:2
[6] Zhang, J. et al (2013)- Amylase: sensitive tumor marker for amylase-producing lung adenocarcinoma- $J$ Thorac Dis : 5: E167-E169.

[7] Agić,D., Bukvić ,G., Grljušić ,S., Bešlo, D., Horvatić , J., Novoselović, D (2009)- Effect of pH on $\alpha$-Amylase Activity and Early Seedling Growth of Red Clover (Trifolium pratense L.)- Not. Bot. Hort. Agrobot. Cluj 37 : 77-80

[8] Zhizhuang X , Reginald Storms, Adrian Tsang(2006); A quantitative starch-iodine method for measuring alpha-amylase. Anal Biochem, 351 ; 146-148.

[9] Nigam, A. and Aiyyagari,A. (2008)- Laboratory Manual in Biochemistry, Immunology and Biotechnology- McGraw-Hill Education.

[10] Bradford,M,M,.(1976). -A rapid and sensitive method for the quantitation of microgram quantities of protein utilizing the principle of protein dye binding. Anal Biochem, 72: 248-254.

[11] Dattatrya,N., Shreekant,M. and Dayashankar,M (2012)- Kokilaksha : a potential ayurvedic herb , IJRAP 3(6) : 780-782.

[12] Nair,D.V., Shridhar, N.B.and Jayakumar,K. (2015)Evaluation of anticancer activity of Asteracantha longifolia in 7,12-Dimethylbenz(a)anthracene-induced mammary gland carcinogenesis in Sprague Dawley rats-Int J Nutr Pharmacol Neurol Dis;5:28-33.

[13] Fedrowitz M, Hass R, Löscher W. (2012)- Effects of $50 \mathrm{~Hz}$ magnetic field exposure on the stress marker $\alpha$ amylase in the rat mammary gland-Int $J$ Radiat Biol. 88(7):556-64

[14] Gupta,P., Bhatnagar, I.,Kim,S.,Verma,A.K. and Sharma,A.(2014)- In-vitro cancer cell cytotoxicity and alpha amylase inhibition effect of seven tropical fruit residues- Asian Pac J Trop Biomed 4(Suppl 2): S665S671

[15] Williams, J.A. and Lee, M. (1976)- Microtubules and Pancreatic amylase release by mouse pancreas in vitro. The Journal of Cell Biology,71:795-806

[16] Owens RA, Hartman PE.(1984)- Alkaline phosphatase isozymes in large intestines and large intestinal tumors of Fischer 344 rats. Biochem Biophys Res Commun.122(2):740-747.

[17] Geller, N.I., Sternberg, C.N.,Penenberg, D.,Scher, H.and Yagoda,A (1991)- Prognostic Factors for Survival of Patients With Advanced Urothelial Tumors Treated With Methotrexate, Vinblastine, Doxorubicin and Cisplatin Chemotherapy. Cancer 67:1525-1531.

[18] Jacob, H.S (1974)- Dysfunctions of the red cell membrane : cited in The Red Blood Cell (Volume I), Academic Press Inc.

[19] Pawar,R.S., Jain,A.P., Kashaw,S.K. and Singhai, A.K (2006)- Haematopoietic activity of Asteracantha longifolia on cyclophosphamide-induced bone marrow suppression- Indian J.Pharm Sci. 68 (3):337-340.

[20] Ellis PA, Smith IE, Hardy JR, Nicolson MC, Talbot DC, Ashley SE, et al. (1995) - Symptom relief with MVP (mitomycin C, vinblastine and cisplatin) chemotherapy in advanced non-small-cell lung cancer. Br J Cancer;71:366-370.

[21] Upamanyu, R., Dwivedi, J. and Saxena, Y. 2009. Hepatotoxic effects of vincristine : an experimental study on albino rats, Indian J Physiol Pharmacol., 53(3):265-270. 


\section{International Journal of Science and Research (IJSR) \\ ISSN (Online): 2319-7064}

Index Copernicus Value (2013): 6.14 | Impact Factor (2015): 6.391

[22] Groninger, E., Meeuswen-de Boer, T., Koopmans, P., Uges,D., Sluiter,W., Veerman,A., Kamps,W. and de Graaf,S (2002)- Pharmacokinetics of Vincristine Monotherapy in Childhood Acute Lymphoblastic Leukemia- Pediatric Research (2002) 52, 113-118.

[23] Desai Z.R, Van den Berg H.W, Bridges J.M, Shanks R.G (1982)- Can severe vincristine neurotoxicity be prevented?- Cancer Chemother Pharmacol. 1982; 8(2):211-4.

\section{Author Profile}

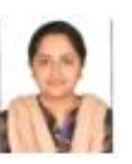

Akshata G Athreya received her B.E Degree in Biotechnology from Acharya Institute of Technology in 2009 and M.Sc Engineering by Research degree in Biotechnology from Sir M.VIT in 2014 affiliated to the VTU, Belgaum. She is presently Senior Research fellow on a Indian Bioresource Information Network (IBIN) project at the School of Ecology and Conservation Lab, University of Agricultural Sciences, G.K.V.K, Bangalore.

Dr. Mrinalini Menon holds a Ph.D degree in Biotechnology from the University of Mysore. Having specialized in Enzymology and Protein chemistry, she has published in peer-reviewed journals and conferences. She is presently working as Associate

Professor at the Dept. of Biotechnology Sir M.VIT, Bangalore. 